- First published in BAKS 7, 2000: 241-52

\title{
(1) How different is Pyongyang speech from Seoul speech?
}

\author{
YEON JAEHOON
}

\section{INTRODUCTION}

There are some noticeable differences in the use of language between 1 North and South Korea. Linguistic differences may be purely dialectal, but it cannot be denied that the language differences between the South and the North are much more than dialectal.

In North Korea, thousands of words have been coined to express socialist ideas and systems; difficult Chinese loanwords have been nativized; expressions pertaining to feudal society and ideology have been eliminated from the newly compiled dictionaries. All these new words, and many common words that have undergone semantic change, may obstruct mutual understanding between the speakers of Korean in the north and south of the peninsula.

In 1966, Kim Il Sung made the following statement in defence of North Korea's standard language, mwunhwae: *

Firmly rooted in the rotten feudal, bourgeois life, the Korean language now spoken in Seoul still uses the type of nasal twangs favoured by women to flirt with men ...; on top of this, English, Japanese, and Chinese loan words, now swarming in Seoul speech, amounting to more than half the total Korean vocabulary, have turned it into a mixed language. Therefore, we should now take Pyongyang speech as the standard since it is the language spoken in Pyongyang, our revolutionary capital ...

This was a kind of official declaration of the linguistic divergence of North Korea from the South. Mwunhwae, 'cultured language', which is spoken in the north as the standard version of speech in Pyongyang, is quite different from the traditional phyocwune 'standard language', which refers to the speech favoured by southerners as the official standard language in Seoul.

\footnotetext{
* In this paper, the Yale system is adopted for the romanization of Korean, rather than the McCuneReischauer system. For various reasons, the Yale system is preferred in discussion of Korean linguistic issues.
} 
The definition of mwunhwae in the Hyuntay Cosenmal Sacen (1981: 1007) is as follows:

It is the language that is cultivated and refined to fit the feelings of the working class centring around the revolutionary capital city [of Pyongyang] under the great leadership of the Labour Party that assumed sovereignty during the reconstruction period of socialism; all [North] Korean people regard it as their standard speech; our mwunhwae was developed by our Party and by the autonomous view of linguistic ideas of our people's revered leader Kim Il Sung and was furthered by our Party's proper language policy after Korean liberation [from Japanese rule in 1945]; it is based on Pyongyang speech, which is an independently promoted beautiful Korean, cast in a nationalistic spirit.

In fact, there exists a large linguistic gap between South and North Korea as a result of a series of systematic innovations introduced into the North Korean language following the abolition of Chinese characters in 1949. Such innovations were motivated to a great extent by political as well as ideological considerations. This paper will examine the linguistic policies implemented in North Korea and differing language usage between North and South Korea.

\section{HISTORICAL REVIEW OF LINGUISTIC POLICIES IN NORTH KOREA}

Linguistic policy in North Korea has been very consistent and the linguistic reforms started along with the political socialization of the state. The whole development of linguistic policy in North Korea can be divided into various stages according to different criteria. For instance, the Korean linguist Kim Minsu (1985) recognizes three periods in the language policy in North Korea on the basis of the two reforms of Korean orthography:

- The period from 1945 to 1954, known as the thongilan sitay ('period of unified orthography'), which adopted the morphophonemic orthography devised by the Korean Language Society in 1933

- The period from 1954 to 1966, known as the chelcapep sitay ('period of divided orthography'), when a set of orthographic conventions different from the ones respected in South Korea was introduced

- The period from 1966 to the present, known as the kyupemcip sitay ('period of prescriptivism')

However, Kim Chin-wu (1978a) criticizes this periodization, saying that 'language policy is more than an orthographic convention'. He proposes three stages: socialization; nativization; and prescriptivism. Yet a third scholar, Kim Huyswuk (1983) considers Kim Il Sung's 1966 'dialogue' as a milestone for periodization. In 1964 and in 1966, Kim Il Sung had two 'dialogues' with North Korean linguists to develop and purify the Korean language. In both discussions, which were promulgated later as Kim Il Sung's kyosi, he called for further nativization and refinement of the language. It was in his second dialogue or teaching that he used for the first time the term mwunhwae to 
designate North Korea's official language. Kim Huyswuk recognizes two main periods: 1945-1966, the period of the exclusive use of han'gul; and 1966 to the present, the period of munhwae or cultural language.

In addition, Kumatani (1990) has periodized the various stages of North Korean language policies as follows:

- A period from 1945 to 1954 , which saw the eradication of illiteracy and the elimination of Chinese characters ('period of Seoul-centred Korean')

- A second period from 1954 to 1964 , known as the phyocwune or 'Common Korean' period

- A third period from 1964 to the present, characterized as the munhwae or 'Pyongyang-centred Korean' period

Whatever the periodization, however, we can notice some major trends in the linguistic policy of North Korea.

The North Korean government at first implemented a policy aimed at the total eradication of illiteracy in North Korea. They claimed that this was achieved by the beginning of 1949 (Kim Chin-wu 1978b; Kumatani 1990). If it was true, it was a remarkable achievement, considering that South Korea still recorded an illiteracy rate of 8.3 per cent in 1958 . Such eradication could not be achieved in a short period of time if people had to learn how to read and write Chinese characters. So Chinese characters were rapidly removed from textbooks, and many literary works using exclusively han'gul were published. Thus, the first stage of North Korean linguistic policy can be called a period of 'democratization' because it gave people access to written information and education. In fact, in North Korea, literacy was an essential prerequisite to making people understand and accept the new ideology. The main purpose of linguistic policy in its first stage was, therefore, to enable the party and the government to spread their ideological policies among the people.

The next step was the nativization of the language in North Korea. 'Koreanization' of vocabulary was the main issue after the abolition of Chinese characters. Sino-Korean and foreign words were discarded and replaced by native Korean translations or coinages such as:

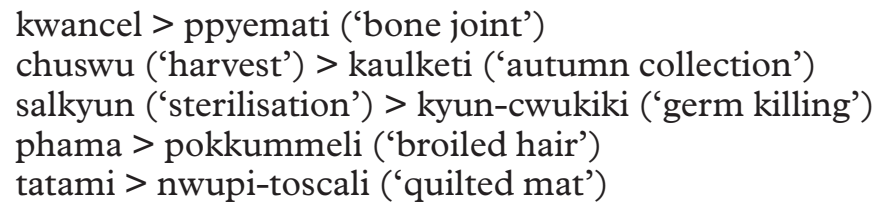

However, it is not true that Sino-Korean words have almost disappeared in North Korea, and the extent of the success of North Korea's language policy on nativization is open to doubt. It is interesting to note that whereas some Sino-Korean words which existed in South Korean were replaced by native words in North Korea, some South Korean native words have changed into 
Sino-Korean words in the North. It is inevitable that a large number of SinoKorean words should still be retained in North Korean. Some Sino-Korean words have the same meaning but different forms in the South and the North:

tongyak sayngsan (NK) - hanyak sayngsan (SK) 'product of oriental medicine' (Shin 1990: 18)

inmin (NK) - kwukmin (SK) 'people'

cosenhwa (NK) - tongyanghwa (SK) 'Oriental painting'

hwukwa (NK) - kyelkwa (SK) 'result'

There are also words which have the same form but two different meanings, such as tongci (see following section for further examples). This category would be capable of causing considerable misunderstandings between readers in North and South Korea.

With regard to orthography, Kim Il Sung in his speech of 3 January 1964 suspended reform in that area. As early as the 1950s, Kim Tubong, one of the nation's leading linguists, proposed reform of the Korean alphabet in order to make it more practical. Although he agreed with the principle, Kim Il Sung presumably feared that it would create too great a divergence between North and South Korean scripts and halted that attempt at revision. According to him, orthographic reform should be put off until after unification. Instead, he called for the abolition of 'undesirable' words and the arbitrary or 'revolutionary' use of 'desirable words'. This started the period which many scholars called 'prescriptivism'. As a result, new dictionaries were compiled: the Cosen Mwunhwae Sacen in 1973 and the Hyuntay Cosenmal Sacen in 1981. In the latter, some newly coined words were added, while certain anti-revolutionary definitions were purposely omitted. Henceforth, language was utilized more and more for political purposes. In his 1966 speech, Kim insisted that language 'is a strong weapon for the realisation of revolution' and emphasized the importance of two language purification movements, the mal tatumki wuntong and the mwunhwae wuntong. One thing to note is that one important linguistic policy was reversed at that occasion. Chinese characters, which had been abolished on the grounds they were the symbol of a privileged minority and an obstacle to general education, were revived in the curriculum in 1966. On the other hand, the campaign of refinement of vocabulary went on.

\section{LINGUISTIC DIFFERENCES BETWEEN NORTH AND SOUTH KOREAN}

Many differences are apparent between the forms of Korean currently spoken in the North and the South, but for reasons of space not all can be mentioned here. Only the most outstanding ones will be noted:

\section{Alphabetical order}

Most people would be surprised to find that the alphabetical order in a dictionary is different. In a North Korean dictionary, for example, words beginning with 'o' come after consonants, namely after hiuh, because 'o' is considered not a consonant, but a mute symbol. 


\section{Vocabulary}

The field of vocabulary shows probably the most serious divergences. Abolition of many Sino-Korean words, standardization of words originating in northern dialects and archaic words or the coining of new words during the so-called mal tatumki wuntong (language purification movement) have been mentioned earlier. Some examples are shown below.

(1) Words different in form but expressing the same concept:

SK sechake ttaylita phoklo toyta hwacangsil sangho yanglowen taycwungkayo yanghay kwancel chuswu 'harvest' salkyun 'sterilization' phama tatami
NK

$$
\text { tapsekita }
$$

palkacita wisayngsil hosang yangsayngwen kwuncungkayo lyohay ppyemati kaulketi kyun-cwukiki pokkummeli nwupi-toscali

'strike hard'
'be exposed'
'toilet'
'mutual'
'old people's home'
'popular song'
'approval'
'bone joint'
'autumn collection'
'germ killing'
'broiled hair'
'quilted mat'

'strike hard'

'toilet'

'mutual'

'old people's home'

'popular song'

'approval'

'bone joint'

'autumn collection'

'broiled hair'

'quilted mat'

(2) Words originating in northern dialects:

\begin{tabular}{lll}
\multicolumn{1}{c}{ SK } & \multicolumn{1}{c}{ NK } & \\
kewi & kesani & 'duck' \\
sangchwu/sangchi & pwulwu & 'lettuce' \\
okswuswu & kangnayngi & 'corn' \\
swule & talkwuci & 'cart' \\
mangkattulita & masuta & 'to break'
\end{tabular}

(3) Other lexical differences, such as words with the same form but whose concept has changed under the influence of socio-political factors in North Korea:

$\begin{array}{lll}\text { epei } & \text { 'parents' (SK) } & \text { 'symbolic title of Kim Il Sung' (NK) } \\ \text { akassi } & \text { 'girl or miss' (SK) } & \begin{array}{l}\text { 'slave of feudalism' (NK) } \\ \text { kwungcen }\end{array} \\ \text { 'palace' (SK) } & \begin{array}{l}\text { 'big, palace-like building used for } \\ \text { social activities' (NK) }\end{array}\end{array}$

\section{Phonetics and phonology}

Phonetic and phonological differences are apparent but do not prevent speakers of North and South Korean from understanding each other. There are some well-known phonetic and phonological features in which North Korean differs from Seoul standard speech.

(1) In Pyongyang speech, the alveolar flap /1/ occurs freely in the wordinitial position, whereas in Seoul speech it is either dropped or replaced by $/ \mathrm{n} /$ : 


\begin{tabular}{lll}
\multicolumn{1}{c}{ SK } & NK & \\
ilon & lilon & 'theory' \\
yokum & lyokum & 'fare' \\
nodong & lodong & 'labour'
\end{tabular}

(2) Similarly, the alveolar nasal $/ \mathrm{n} /$ occurs freely in the word-initial position in Pyongyang speech even when followed by the semi-vowel $/ y /$, whereas it is dropped in Seoul speech:

\begin{tabular}{lll}
\multicolumn{1}{c}{ SK } & NK & \\
yeca & nyeca & 'woman', \\
yelum & nyelum & 'summer'
\end{tabular}

The word-initial occurrence of $/ 1 /$ and $/ \mathrm{n} /$ in North Korean is already well known as one of the typical dialectal features of Pyongyang speech and has now been officially recognized in both speech and writing.

(3) The back vowels /a/ and /e/, when followed by vowel /i/ within the word, are often changed to the front vowels /ae/ and /e/ respectively, as a result of 'Umlaut'. This is a widespread feature in spoken language in both Pyongyang and Seoul speech, but in North Korea such assimilated forms are accepted as standard in both spoken and written language, whereas in the South Korean writing system only the original forms are taken as standard:

\begin{tabular}{lll}
\multicolumn{1}{c}{ SK } & NK & \\
engtengi & engteyngi & 'hip, bottom' \\
muteki & muteyki & 'pile'
\end{tabular}

(4) One of the most noticeable features of North Korean is found in stress and intonation patterns. Stronger stress and higher pitch are used in North Korean by comparison with South Korean. To speakers in the South, North Korean sounds aggressive and militant. Such a jarring impression is no doubt conveyed by the stress and intonation system characteristic of North Korean. It is interesting to note that such an intonation is interpreted in the North as 'high-spirited, courageous and revolutionarily refined', words used by Kim Il Sung in a speech he made at a meeting of North Korean linguists. He claimed that such pronunciation was suited to the expression of ideas and feelings of people who were engaged in revolutionary activities.

\section{Syntax and morphology}

Syntactic structure also shows some interesting differences:

(1) The plural concept, expressed formally by -tul, is used much more frequently in the North. This can sound odd to South Koreans but this does not affect the meaning:

ketayhan sengkwa tul ul ilwukhayssko ... 'achieved great results [plural] ...' 
(2) Another characteristic of North Korean syntax is that verbal clause strucuture is preferred to nominal phrases, if they are interchangeable, especially when used as the title of newspaper articles, etc. It is in complete contrast to the usage in South Korea, where a nominal phrase is more often used. This is presumably due to North Korean reluctance to use Sino-Korean words. Whereas Sino-Korean words allow the concise nominal expression, North Korean has to depend on verbal phrases to express the same message, using a pure Korean verb:

a. mokcek talseng-ulo (sunglica-ka toyca) SK

'With goal attainment, (let's be a victor)'

mocek-ul ilukhaye (sunglica-ka toyca) NK

'Attaining the goal, (let's be a victor)' (Lee Hyong-bok, 1990: 80)

b. ene-wa cengchi 'language and politics' SK

ene muncey-nun cengchicek muncey-ita NK

'A linguistic problem is a political problem'

c. celyak cengchayk 'frugality policy' SK

celyakhako celyakhako tto celyakhaca NK

'Let's economize, economize and economize!' (Hong, 1991: 162)

With regard to syntactic differences, another interesting point was made by Shin (1995: 332f). After comparing newspaper headlines in Choson Ilbo and Rodong Sinmun, she concluded that the Choson Ilbo preferred sentence structures in which a patient was in the subject position and an agent was sometimes deleted or left in the oblique position, whereas the Rodong Sinmun preferred sentence structures in which an agent was normally positioned as subject.

(3) In North Korean, the prospective modifier is used when the present modifier would be used in South Korean. Thus, the construction '(u)l tey tayhaye' is frequently used, which could be a counterpart of South Korean '-nun kes ey tayhaye'. Also '-(u)l taysin ey' is used for South Korean '-nun taysin ey', meaning 'instead of' (Nam and Ceng 1990: 30):

Cosene uy thukseng ul sallye naka tey tayhaye

'On (about) developing the characteristics of the Korean language'

Cip ey tolakal taysin ey ...

'Instead of going back the house ...'

With respect to morphology, a large number of words have been created by using some derivational affixes, such as -cek, -hi-, -lop-, -wu-, -ci, -mac- and -ca, beyond the function to which they are usually limited in Seoul Korean (cf. Lee 1990: 77; Hong 1991: 161; Nam and Ceng 1990: 30):

$\begin{array}{ll}\text {-hi-: } & \text { kip-hi- } \\ & \text { sayngkak-hi- } \\ \text {-mac-: } & \text { kuphay-mac- }\end{array}$

'deepen'

'be in a terrible hurry' 


\begin{tabular}{|c|c|c|}
\hline -wu-: & $\begin{array}{l}\text { pappa-mac- } \\
\text { mwukki-wu- }\end{array}$ & $\begin{array}{l}\text { 'be terribly busy' } \\
\text { 'be tied down' }\end{array}$ \\
\hline -ci-: & $\begin{array}{l}\text { palay-wu-, calay-wu- } \\
\text { chalye-ci-, cwuleng-ci- }\end{array}$ & \\
\hline -na-: & pwulewe-na-, & coha-na-, tewe-na- \\
\hline $\begin{array}{l}\text {-nase-: } \\
\text {-cek-: }\end{array}$ & $\begin{array}{l}\text { ttelchye-nase-, towa-nase- } \\
\text { hakkyo-cek }\end{array}$ & 'of the school' \\
\hline
\end{tabular}

Another different trend worth noting is the simplification of speech levels in North Korean. Traditionally, five different speech levels have been recognized in Korean, depending on the relationship between the speaker and the hearer, although there are some disagreements among scholars on this point (cf.Yeon, 1996). However, in North Korean, these five levels of speech style seem to have been reorganized and reduced to three levels, namely, polite style, equal style, and low style. Some of the reasons for simplifying the five speech levels to three were suggested by Lee Hyun-bok (1990: 79), when he wrote: 'We have three levels of speech style ... suitable for the people engaged in the construction of a socialist country ... whereby we can respect seniors, express affection to juniors, and be friendly with colleagues and friends.'

If one were to consider speech levels undesirable and incompatible in a socialist ideology, perhaps a complete abolition of speech levels might be more desirable. On the other hand, the honorific suffix/-si-/ is more extensively used in North Korean, a practice that might have been encouraged by the excessive cult of Kim Il Sung, even though it is in contradiction to the simplification of speech levels.

\section{Stylistics}

In North Korean, style, as a powerful weapon for revolution, is regarded as one of the most important elements in carrying out the social function of language. Kim Il Sung claimed that the stylistic characteristics of cultured language must reflect the needs of the working class. The characteristics of North Korean stylistics are: a preference for short sentences to express militant emotion; preferences for a style embodying commands and exclamation, and for an emphatic style achieved through use of repetition; the use of a verbal clause rather than a nominal clause in a title; and a preference for spoken style over written style.

\section{CONCLUSION}

This paper has examined some noticeable differences in language use between North and South Korea. Such differences could be regarded as serious divergences or minor ones, depending on one's viewpoint. Whereas some scholars like Shin Hyun-Sook (1990) minimize the extent of differentiation between North and South Korean, others like Kim Chin-wu (1991) claim that linguistic differentiation is not only a real phenomenon but has historical (i.e. dating to before the division of the peninsula) and social reasons.

Shin (1990) has carried out a study of the North Korean newspaper 
Rodong Sinmun and concludes that South and North Korean show few differences regarding form, meaning and usage. Kim Chin-wu (1991), on the other hand, claims that there has been a great deal of divergence and seeks to discern its causes. Chinese had been the official written language among the élite until the late 19th century, and at the end of the colonial period, the Korean language was banned by the Japanese. As a consequence, there was no standardized language in the Korean peninsula when the country was divided. As we know, each part has implemented a separate policy since division. In North Korea, language has been shaped by social requirements dictated by Communist ideology and most of the features of North Korean today are consequently related to that ideological thought.

Nevertheless, both languages have a common phonological and grammatical structure and people both North and South have no real difficulties in communicating except for a few divergences in vocabulary usage. In conclusion, although some differences are found in the fields of morphology, syntax, phonetics, phonology and stylistics, it may be assumed that the extent of such differentiation cannot reverse belief in the homogeneity of the North and South Korean languages. 